\title{
Urea-treated neem (Azadirachta indica A. juss) seed kernel cake as a protein supplement for lambs
}

\author{
L.M. Musalia ${ }^{1, *}$, S. Anandan, V.R.B. Sastry, D.K. Agrawal \\ Division of Animal Nutrition, Indian Veterinary Research Institute, Izatnagar 243 122, India
}

Accepted 1 June 1999

\begin{abstract}
The performance of 12 male and 12 female Mandya $\times$ Merino lambs weighing between 5.4 and $12.4 \mathrm{~kg}$ was investigated by feeding neem seed kernel cake (NSKC) after treatment with 2.5\% urea. Lambs of each sex were allotted randomly to concentrate mixture containing either 30\% groundnut cake (GNC) or 33\% urea-treated neem seed kernel cake (UTNSKC). Over a period of 182 days the concentrate mixtures fed, to meet $70 \%$ of the protein requirements of the lambs, were given with oat hay offered ad libitum. Replacement of GNC by UTNSKC in the concentrate mixture depressed $(P<0.001)$ the digestibility of dietary dry matter (DM) (69.9 vs. 63.3), crude protein (CP) (71.1 vs. 65.1) and gross energy (69.9 vs. 64.3). Digestibility of ether extract (70.5 vs. 77.6$)$ was increased $(P<0.001)$ and there was no effect on crude fibre ( 41.6 vs. 43.8$)$ digestibility, whereas the daily intake of DM (72.51 vs. $\left.65.77 \mathrm{~g} / \mathrm{M}^{0.75}\right)$ and GE $\left(1.33\right.$ vs. $\left.1.21 \mathrm{MJ} / \mathrm{M}^{0.75}\right)$ were higher $(P<0.05)$ in lambs fed UTNSKC, dietary differences had no effect on digestible energy intake and $\mathrm{N}$ retention. The rumen liquor from lambs fed UTNSKC had lower concentrations of total volatile fatty acids $(P<0.01)$, total $\mathrm{N}(P<0.01)$ and ammonia $\mathrm{N}(P<0.01)$ and depressed activities of cellulase $(P<0.05)$, protease $(P<0.01)$ and urease $(P<0.01)$ enzymes. Average daily gains were similar $(P>0.05)$ in lambs fed UTNSKC (74.0 g) and GNC (80.3 g). More DM (7.08 vs. $\left.8.04 \mathrm{~kg} \mathrm{~kg}^{-1}\right)$ and CP $\left(1.10 \mathrm{vs.} 1.23 \mathrm{~kg} \mathrm{~kg}^{-1}\right)$ were required for growth on the ration containing UTNSKC. Feeding UTNSKC had no effect on blood profile, wool growth and carcass characteristics. Kidneys from animals fed UTNSKC were enlarged $(P<0.05)$ as compared to those fed GNC. Microcalculi were observed in all lambs fed UTNSKC. The results indicated that feeding UTNSKC depressed the digestibility of nutrients, which was attributed to the low activities of enzymes in the rumen. (C) 2000 Published by Elsevier Science B.V. All rights reserved.
\end{abstract}

Keywords: Digestibility; Growth; Lambs; Neem seed kernel cake; Urea treatment

\section{Introduction}

India has an annual potential of producing 100000 tones of neem seed kernel cake (NSKC), a

\footnotetext{
*Corresponding author. Tel.: 254-37-61282.

E-mail address: eu-cs@net2oooke.com (L.M. Musalia).

${ }^{1}$ Present address: Department of Animal Science, Egerton University, PO Box 536, Njoro, Kenya.
}

good source of crude protein $(\mathrm{CP})(33-40 \% \mathrm{CP})$ with low crude fibre $(\mathrm{CFi})(11-20 \% \mathrm{CFi})$ content. However, when this cake was fed without any treatment, growth was depressed, despite similar intake of digestible energy (DE) and digestible CP (Rajagopal and Nath, 1981). Consequently, the cake has been treated by various methods, including water washing (Nath et al., 1983; Agrawal et al., 1987), and alkali treatment (Katiyar et al., 1991) to avoid the growth depression 
effects. However, in anticipation of any side effects which may be associated with residual alkali and dry matter (DM) loss of $22 \%$ when alkali treatment is accompanied by water-washing, Reddy (1992) postulated that alkali-treatment could be achieved by urea (3.0\%) ammoniation of the cake. Urea-treated cake was found to be a good source of protein for growing buffalo calves (Reddy, 1992), broilers (Nagalakshmi, 1993) and goats (Anandan et al., 1996). The present study was designed to investigate the possibility of total replacement of groundnut cake (GNC) by ureatreated neem seed kernel cake (UTNSKC), as a major source of protein, in concentrate mixture offered to growing lambs.

\section{Material and methods}

\subsection{Performance of animals}

Urea-treated NSKC was prepared by soaking NSKC in water $\left(1.21 \mathrm{~kg}^{-1}\right)$ containing fertilizer grade urea $(2.5 \%)$ to make soft dough. The 'dough' was stirred daily for 5 days in airtight steel drum. The dough was then sun-dried for 5 days and ground through a $2 \mathrm{~mm}$ screen. Two concentrate mixtures were formulated to contain $20 \% \mathrm{CP}$ with about $65 \%$ of the protein originating from either GNC or UTNSKC. The concentrate containing UTNSKC was made of $33 \%$ UTNSKC, $57 \%$ maize and $7 \%$ wheat bran, while the control consisted of $30 \%$ GNC, 59\% maize and $8 \%$ wheat bran. Mineral mixture and salt were added at $2 \%$ and $1 \%$, respectively, to the concentrate mixtures.

Post-weaning Mandya $\times$ Merino crossbred lambs (12 males and 12 females) aged between 4 and 6 months with initial body weight from 5.4 to $12.5 \mathrm{~kg}$ were used. The lambs were blocked by body weight and sex and allocated randomly to one of two treatments in which animals were offered a concentrate mixture containing either GNC or UTNSKC.

The lambs were housed in a well-ventilated house with facilities for individual feeding and watering. They were vaccinated against enterotoxaemia at the beginning of the experiment and were dewormed and treated with coccidiostat at intervals of one month. During the 182 day feeding period, concentrates were offered at 7.00 a.m. to meet $70 \%$ of the animals' protein requirements for daily gains of $100 \mathrm{~g}$ based on their body weight (NRC, 1985) and oat hay was offered ad libitum after 10.00 a.m. The amount of concentrate offered was adjusted fortnightly, after weighing the animals. Daily feed intakes were recorded fortnightly for four days starting on 6th to 9 th day, after weighing the animals. The difference between feed offered and residual was recorded as the daily feed intake. The mean was calculated as the fortnightly daily feed intake and was expressed per $\mathrm{kg}$ metabolic weight $\left(\mathrm{M}^{0.75}\right)$. Daily feed intake for the entire feeding period of 182 days was taken as the average of 13 fortnights. Daily intakes of CP and DE were estimated from the daily DM intake and the data of digestibility trials. Lambs were weighed at the beginning of the study and subsequently every fortnight. Average daily gains for individual animals were calculated from regression of fortnightly body weight on time.

A mid side patch of $10 \times 10 \mathrm{~cm}$ was clipped to skin level on the right side of each lamb at the beginning of the experiment. The same patch was clipped after 182 days of the feeding trial. Wool from the patch was cleaned by ether and oven-dried at $100^{\circ} \mathrm{C}$ before weighing. Wool growth was expressed in $\mathrm{mg}$ per day per $100 \mathrm{~cm}^{2}$ of skin. Fibre diameter and medullation were estimated on about 300 fibres by projection microscope. Lengths of five small staples of wool from the anterior area of the patch were measured to obtain the mean staple length.

Approximately $10 \mathrm{ml}$ of blood was collected from the jugular vein after 150 days of feeding. The blood was refrigerated at $4{ }^{\circ} \mathrm{C}$ and serum was collected after $12 \mathrm{~h}$. Serum glutamic oxaloacetate transaminase (SGOT) and serum glutamic pyruvate transaminase (SGPT) activities were determined by methods described by Reitman and Frankel (1957). Alkaline phosphatase activity, blood urea and blood glucose were estimated by methods of Bergmeyer (1974), Rahmatulla and Boyde (1980) and Cooper and McDaniel (1970), respectively. At the end of the feeding period four males from each group were slaughtered to assess the carcass characteristics and observe any pathological changes.

\subsection{Digestibility studies}

Apparent digestibility was measured after 70 and 150 days of offering the concentrate mixtures using 
four animals of each sex from each treatment. The animals were transferred to metabolic cages where their respective feeding regimes were continued. The sheep were fed for an adaptation period of four days followed by total collection of faeces and urine for six days. An attendant collected faeces, whereas urine was collected in a plastic container that was kept below the cage. Feed residues were weighed daily at 7.00 a.m. before offering fresh weighed concentrates. Hay equivalent to $110 \%$ of the previous day's intake was offered at 10.00 a.m. Hay and concentrates used as well as feed residues were sampled daily for DM determination and bulked for eventual chemical analyses. Subsamples of daily outputs of faeces and urine for each animal were pooled for chemical analysis.

Proximate composition of feeds, feed residues and faecal samples were determined by methods described in AOAC (1984). Water-soluble carbohydrates (WSC) and urea content in feeds were estimated by the methods described by Deriaz (1964) and Hogg (1967), respectively. The gross energy (GE) of the feeds and faeces were determined by an adiabatic oxygen bomb calorimeter.

\subsection{Rumen fermentation study}

At the end of the growth study, ruminal fluid was collected with an oesophageal tube on three consecutive days from two male lambs on each ration. The first collection was done before offering concentrate and thereafter at intervals of $2 \mathrm{~h}$ up to the eighth hour.

The $\mathrm{pH}$ was determined immediately after collection by glass electrode. The sample was strained through four layered muslin cloth. About $10 \mathrm{ml}$ of the strained rumen liquor (SRL) was acidified with five drops of 1:4 sulphuric acid and frozen for analysis of total and ammonia N. $5 \mathrm{ml}$ of SRL was pipetted into plastic vials and preserved by adding two drops of saturated solution of mercuric chloride for estimation of total volatile fatty acids (TVFA). $10 \mathrm{ml}$ of the sample collected after $4 \mathrm{~h}$ of feeding was sonicated at 8 microns for $5 \mathrm{~min}$, before straining, followed by centrifugation at $15000 \times \mathrm{g}$ for $15 \mathrm{~min}$ under refrigeration condition. The supernatant was used for analysis of enzymes activities. Total $\mathrm{N}$ was analysed by Kjeldahl method and ammonia $\mathrm{N}$ was estimated by steam distillation of acidified samples in the presence of $40 \% \mathrm{NaOH}$. Total volatile fatty acids were estimated by steam distillation. Activities of carboxymenthyl cellulase and $\alpha$-amylase in rumen liquor were estimated by incubating, in a water bath at $39^{\circ} \mathrm{C}$ for $15 \mathrm{~min}$, an assay mixture containing $0.5 \mathrm{ml}$ distilled water, $1 \mathrm{ml}$ substrate $(1 \%$ carboxymethyl cellulose or $0.25 \%$ soluble starch in $0.05 \mathrm{M}$ phosphate buffer, $\mathrm{pH}$ 7) and $0.5 \mathrm{ml}$ of sonicated rumen liquor. The reaction was stopped by adding $3 \mathrm{ml} 3$,5-dinitrosalicylic acid (DNS) and the reducing sugars produced were estimated by the method of Miller (1959). One unit of enzyme activity was defined as the amount which produced $1 \mu \mathrm{mol}$ of glucose per minute under the assay conditions.

Protease activity was estimated by an assay mixture containing $0.25 \mathrm{ml}$ of substrate $(1 \%$ casein), $1 \mathrm{ml}$ phosphate buffer $(0.05 \mathrm{M}, \mathrm{pH} 7), 0.5 \mathrm{ml}$ distilled water and $0.25 \mathrm{ml}$ rumen liquor. This was incubated at $40^{\circ} \mathrm{C}$ for $2 \mathrm{~h}$ and the reaction was stopped by adding $2 \mathrm{ml}$ of $20 \%$ trichloroacetic acid (TCA). The soluble protein was estimated in the supernatant, after centrifugation, by the method described by Lowry et al. (1951). One unit of enzyme activity was defined as the quantity which produced $1 \mathrm{mg}$ of soluble protein per hour under assay conditions.

Urease activity was estimated by incubating $0.25 \mathrm{ml}$ rumen liquor, $0.25 \mathrm{ml}$ substrate $(0.01 \mathrm{M}$ urea $)$ and $0.5 \mathrm{ml}$ phosphate buffer $(0.1 \mathrm{M}, \mathrm{pH} 7)$ for $15 \mathrm{~min}$ at $37^{\circ} \mathrm{C}$. The ammonia released was estimated by the method of Weatherburn (1967). One unit of enzyme activity was defined as the quantity which produced $1 \mu$ mole of ammonia per minute under assay conditions.

\subsection{Statistical analysis}

Data were subjected to a two-way analysis of variance and differences among means of diets and sexes were tested (Snedecor and Cochran, 1980).

\section{Results}

\subsection{Digestibility study}

The chemical composition of the feedstuffs and concentrate mixtures offered to the animals are given in Table 1. There were no significant differences between data from the digestibility trials carried out 
Table 1

Chemical composition (\%) of concentrate mixtures, hay, NSKC, UTNSKC and GNC

\begin{tabular}{|c|c|c|c|c|c|c|}
\hline & \multicolumn{2}{|c|}{ Concentrate mixture containing } & \multicolumn{4}{|c|}{ Feedstuffs } \\
\hline & GNC & UTNSKC & Hay & NSKC & UTNSKC & GNC \\
\hline Organic matter & 92.38 & 90.00 & 89.06 & 84.34 & 83.50 & 92.09 \\
\hline Crude protein & 19.42 & 20.20 & 7.84 & 33.68 & 40.33 & 43.48 \\
\hline Ether extract & 2.52 & 4.85 & 1.25 & 8.60 & 8.46 & 1.23 \\
\hline Crude fibre & 5.82 & 7.00 & 38.01 & 13.64 & 15.38 & 12.13 \\
\hline Ash & 7.62 & 10.00 & 10.95 & 15.66 & 16.50 & 7.91 \\
\hline Water soluble carbohydrates & 7.28 & 4.40 & 2.48 & 2.37 & 1.29 & 9.93 \\
\hline Urea & 0 & 0.83 & 0 & 0 & 2.49 & 0 \\
\hline
\end{tabular}

after 70 and 150 days of feeding and the main results are shown as pooled values across the feeding period (Tables 2-4). Lambs offered a concentrate based on UTNSKC consumed $30 \%$ more hay than those fed GNC resulting in approximately $10 \%$ more DM intake although these differences were not statistically significant. Replacement of GNC with UTNSKC in the concentrate significantly changed the chemical composition of the total rations consumed without affecting the CP content (Table 2).

Feeding UTNSKC depressed $(P<0.001)$ the apparent digestibility of DM, organic matter (OM), CP and GE, but increased $(P<0.001)$ that of ether extract (EE) while crude fibre (CFi) was not affected (Table 3). Sex did not affect apparent digestibilities of the proximate fractions apart from EE where the digestibility was higher $(P<0.05)$ in female lambs.
Diet and sex differences did not affect the average daily $\mathrm{N}$ retention by lambs (Table 4), whereas the daily intake of DE per $\mathrm{kg} \mathrm{M}^{0.75}$ was comparable between diets, the intake of GE, per $\mathrm{M}^{0.75}$, was higher $(P<0.001)$ on the ration containing UTNSKC and in males as compared to control diet and female lambs, respectively.

\subsection{Rumen fermentation pattern}

The $\mathrm{pH}$ and the concentrations of TVFA, total $\mathrm{N}$ and ammonia $\mathrm{N}$ were lower $(P<0.01)$ in the rumen liquor from lambs fed UTNSKC (Table 5). The ration containing UTNSKC depressed the activities of cellulase $(P<0.05)$, protease $(P<0.01)$ and urease $(P<0.01)$ but there was no difference in the activity of amylase in the rumen liquor (Table 5).

Table 2

Daily feed intake and chemical composition of rations containing either UTNSKC or GNC offered to growing lambs

\begin{tabular}{|c|c|c|c|c|c|c|c|}
\hline \multicolumn{2}{|l|}{ GNC } & \multicolumn{2}{|c|}{ UTNSKC } & \multirow[t]{2}{*}{$\operatorname{Sed}^{\mathrm{a}}$} & \multicolumn{3}{|c|}{ Significance of difference } \\
\hline Male & Female & Male & Female & & $\begin{array}{l}\text { Protein } \\
\text { source }(\mathrm{P})\end{array}$ & $\begin{array}{l}\text { Sex } \\
\text { (S) }\end{array}$ & $\mathrm{P} \times \mathrm{S}$ \\
\hline
\end{tabular}

\begin{tabular}{|c|c|c|c|c|c|c|c|c|}
\hline \multicolumn{9}{|l|}{ Feed consumed $\left(g\right.$ day $\left.^{-1}\right)$} \\
\hline Concentrate & 390 & 394 & 390 & 394 & 21.8 & NS & NS & NS \\
\hline Hay & 256 & 168 & 333 & 218 & 60.5 & NS & NS & NS \\
\hline Total & 646 & 562 & 723 & 612 & 79.7 & NS & NS & NS \\
\hline Concentrate/hay & 1.9 & 2.8 & 1.5 & 1.9 & 0.46 & $*$ & NS & NS \\
\hline \multicolumn{9}{|l|}{ Chemical composition (\%) } \\
\hline Organic matter & 91.4 & 91.8 & 89.6 & 89.5 & 0.38 & $* * *$ & NS & NS \\
\hline Crude protein & 14.9 & 16.2 & 14.9 & 15.6 & 0.64 & NS & $*$ & NS \\
\hline Ether extract & 2.3 & 2.3 & 3.6 & 3.8 & 0.14 & $* * *$ & NS & NS \\
\hline Crude fibre & 16.1 & 13.5 & 18.2 & 16.5 & 1.27 & $* *$ & $*$ & NS \\
\hline Water soluble carbohydrates & 5.5 & 5.9 & 3.6 & 3.7 & 0.17 & $* * *$ & $*$ & NS \\
\hline
\end{tabular}

${ }^{\mathrm{a}}$ Number of observations per mean $=8$.

$*$, **, ***, NS $=P<0.05, P<0.01, P<0.001, P>0.05$, respectively. 
Table 3

Digestibility of nutrients in rations containing UTNSKC as a replacement of GNC

\begin{tabular}{|c|c|c|c|c|c|c|c|}
\hline \multicolumn{2}{|l|}{ GNC } & \multicolumn{2}{|c|}{ UTNSKC } & \multirow[t]{2}{*}{$\mathrm{Sed}^{\mathrm{a}}$} & \multicolumn{3}{|c|}{ Significance of difference } \\
\hline Male & Female & Male & Female & & $\begin{array}{l}\text { Protein } \\
\text { source }(\mathrm{P})\end{array}$ & $\begin{array}{l}\text { Sex } \\
\text { (S) }\end{array}$ & $\mathrm{P} \times \mathrm{S}$ \\
\hline
\end{tabular}

\begin{tabular}{|c|c|c|c|c|c|c|c|c|}
\hline \multicolumn{9}{|l|}{ Apparent digestibility (\%) } \\
\hline Dry matter & 68.4 & 71.3 & 63.2 & 63.3 & 1.45 & $* * *$ & NS & NS \\
\hline Organic matter & 70.2 & 73.2 & 65.5 & 65.5 & 1.48 & $* * *$ & NS & NS \\
\hline Crude protein & 69.5 & 72.5 & 64.4 & 65.7 & 2.20 & $* * *$ & NS & NS \\
\hline Ether extract & 67.8 & 73.5 & 76.5 & 78.7 & 2.11 & $* * *$ & $*$ & NS \\
\hline Crude fibre & 43.5 & 43.9 & 45.8 & 41.8 & 3.87 & NS & NS & NS \\
\hline Energy & 68.3 & 71.5 & 64.3 & 64.3 & 1.47 & $* * *$ & NS & NS \\
\hline Digestible energy $\left(\mathrm{MJ} \mathrm{kg}^{-1} \mathrm{DM}\right)$ & 12.4 & 13.0 & 11.8 & 11.8 & 0.31 & $* * *$ & NS & NS \\
\hline Digestible crude protein $\left(\mathrm{g} \mathrm{kg}^{-1} \mathrm{DM}\right)$ & 103.8 & 117.6 & 96.7 & 103.0 & 7.06 & $*$ & NS & NS \\
\hline
\end{tabular}

${ }^{\mathrm{a}}$ Number of observations per mean $=8$.

$*, * *, * * *, \mathrm{NS}=P<0.05, P<0.01, P<0.001, P>0.05$, respectively.

Table 4

Nitrogen balance and energy metabolism in lambs fed rations containing UTNSKC as a replacement of GNC

\begin{tabular}{|c|c|c|c|c|c|c|c|}
\hline \multicolumn{2}{|l|}{ GNC } & \multicolumn{2}{|c|}{ UTNSKC } & \multirow[t]{2}{*}{$\operatorname{Sed}^{\mathrm{a}}$} & \multicolumn{3}{|c|}{ Significance of difference } \\
\hline Male & Female & Male & Female & & $\begin{array}{l}\text { Protein } \\
\text { source }(\mathrm{P})\end{array}$ & $\begin{array}{l}\text { Sex } \\
(\mathrm{S})\end{array}$ & $\mathrm{P} \times \mathrm{S}$ \\
\hline
\end{tabular}

\begin{tabular}{|c|c|c|c|c|c|c|c|c|}
\hline \multicolumn{9}{|c|}{ Nitrogen utilization $\left(g\right.$ day $\left.^{-1}\right)$} \\
\hline Intake & 15.1 & 14.2 & 16.8 & 15.2 & 1.33 & NS & NS & NS \\
\hline Faecal loss & 4.6 & 3.9 & 6.1 & 5.2 & 0.64 & NS & NS & NS \\
\hline Urinary loss & 2.3 & 2.4 & 2.5 & 2.6 & 0.59 & NS & NS & NS \\
\hline Retained & 8.2 & 7.9 & 8.1 & 7.5 & 0.55 & NS & NS & NS \\
\hline \multicolumn{9}{|c|}{ Energy $\left(M J\right.$ day $\left.^{-1}\right)$} \\
\hline Feed consumed & 11.72 & 10.12 & 13.21 & 11.17 & 1.420 & NS & NS & NS \\
\hline Faeces & 3.75 & 2.89 & 4.82 & 3.98 & 0.573 & $* *$ & * & NS \\
\hline \multicolumn{9}{|c|}{ Energy intake $\left(M J / k M^{0.75}\right.$ aay $\left.^{-1}\right)$} \\
\hline Gross & 1.275 & 1.145 & 1.414 & 1.237 & 0.1163 & $* * *$ & $* * *$ & NS \\
\hline Digestible & 0.868 & 0.816 & 0.908 & 0.794 & 0.0303 & NS & NS & NS \\
\hline
\end{tabular}

${ }^{\text {a }}$ Number of observations per mean $=8$.

$*, * *, * * *, \mathrm{NS}=P<0.05, P<0.01, P<0.001, P>0.05$, respectively.

\subsection{Performance of growing lambs}

Table 6 shows results on performance of growing lambs for a feeding period of 182 days. Urea-treated cake improved $(P<0.05)$ the DM intake but there were no differences in daily intake of $\mathrm{CP}$ and DE between diets and sexes. Average daily gain of male lambs was higher $(P<0.05)$ than female lambs but differences between diets were not significant. Utilization of $\mathrm{DM}$ and $\mathrm{CP}$ for growth was less efficient on the ration containing
UTNSKC while utilization of DE was comparable on the two diets. Nutrients were utilized more efficiently for growth by male lambs as compared to female lambs.

Whereas wool growth and staple length were superior in female lambs as compared to male lambs, similar $(P>0.05)$ values were observed between diets. Neither diet nor sex varied the blood biochemical constituents (Table 7). Killing out proportion and yield of wholesale cuts were also comparable on both diets (Table 8). 
Table 5

Rumen fermentation pattern of male lambs fed UTNSKC as a replacement of GNC in concentrate mixture

\begin{tabular}{|c|c|c|c|c|}
\hline Attribute & $n^{\mathrm{a}}$ & GNC & UTNSKC & $\begin{array}{l}\text { Significance } \\
\text { of difference }\end{array}$ \\
\hline $\begin{array}{l}\mathrm{pH} \\
\pm \mathrm{SE}\end{array}$ & 30 & $\begin{array}{l}7.2 \\
0.06\end{array}$ & $\begin{array}{l}7.4 \\
0.04\end{array}$ & $* *$ \\
\hline $\begin{array}{l}\text { TVFA }\left(\mathrm{mEq} 100^{-1} \mathrm{ml}\right) \\
\pm \mathrm{SE}\end{array}$ & 30 & $\begin{array}{l}7.4 \\
0.38\end{array}$ & $\begin{array}{l}60 \\
0.21\end{array}$ & $* *$ \\
\hline $\begin{array}{l}\left.\text { Total N (mg } 100^{-1} \mathrm{ml}\right) \\
\pm \mathrm{SE}\end{array}$ & 30 & $\begin{array}{r}22.7 \\
0.87\end{array}$ & $\begin{array}{c}12.7 \\
0.52\end{array}$ & $* *$ \\
\hline $\begin{array}{l}\text { Ammonia } \mathrm{N}\left(\mathrm{mg} 100^{-1} \mathrm{ml}\right) \\
\pm \mathrm{SE}\end{array}$ & 30 & $\begin{array}{l}5.7 \\
0.26\end{array}$ & $\begin{array}{l}3.5 \\
0.23\end{array}$ & $* *$ \\
\hline $\begin{array}{l}\text { Enzymes activity }\left(U^{2} / m l\right) \\
\text { Cellulase } \\
\pm \mathrm{SE}\end{array}$ & 6 & $\begin{array}{l}0.44 \\
0.025\end{array}$ & $\begin{array}{l}0.32 \\
0.037\end{array}$ & $*$ \\
\hline $\begin{array}{l}\text { Amylase } \\
\pm \mathrm{SE}\end{array}$ & 6 & $\begin{array}{l}0.38 \\
0.008\end{array}$ & $\begin{array}{l}0.37 \\
0.017\end{array}$ & NS \\
\hline $\begin{array}{l}\text { Protease } \\
\pm \mathrm{SE}\end{array}$ & 6 & $\begin{array}{l}5.53 \\
0.402\end{array}$ & $\begin{array}{l}2.63 \\
0.560\end{array}$ & $* *$ \\
\hline $\begin{array}{l}\text { Urease } \\
\pm \mathrm{SE}\end{array}$ & 6 & $\begin{array}{l}1.87 \\
0.054\end{array}$ & $\begin{array}{l}1.48 \\
0.047\end{array}$ & $* *$ \\
\hline
\end{tabular}

\footnotetext{
${ }^{\mathrm{a}}$ Number of observations.
}

${ }^{\mathrm{b}}$ Enzyme units were described as the quantity of enzyme that produced $1 \mu$ mole of glucose per minute, $1 \mathrm{mg}$ of soluble protein per hour and $1 \mu$ mole of ammonia per minute under assay conditions for cellulase and amylase, protease and urease, respectively.

$*, * *, * * *, \mathrm{NS}=P<0.05, P<0.01, P<0.001, P>0.05$, respectively.

\section{Table 6}

Intake of DM, CP and DE, growth, efficiency of body weight gain and wool growth and quality of growing lambs fed concentrate mixture containing UTNSKC as a replacement of GNC

\begin{tabular}{|c|c|c|c|c|c|c|c|}
\hline \multicolumn{2}{|l|}{ GNC } & \multicolumn{2}{|c|}{ UTNSKC } & \multirow[t]{2}{*}{$\mathrm{Sed}^{\mathrm{a}}$} & \multicolumn{3}{|c|}{ Significance of difference } \\
\hline Male & Female & Male & Female & & $\begin{array}{l}\text { Protein } \\
\text { source }(\mathrm{P})\end{array}$ & $\begin{array}{l}\text { Sex } \\
(S)\end{array}$ & $\mathrm{P} \times \mathrm{S}$ \\
\hline
\end{tabular}

\begin{tabular}{|c|c|c|c|c|c|c|c|c|}
\hline \multicolumn{9}{|c|}{ Intake (g or $M J / k_{g} M^{0.75}$ day $^{-1}$ ) } \\
\hline Dry matter & 66.3 & 65.7 & 71.6 & 69.0 & 2.76 & $*$ & NS & NS \\
\hline Crude protein & 9.9 & 10.6 & 10.7 & 10.8 & 0.42 & NS & NS & NS \\
\hline Digestible energy & 0.850 & 0.906 & 0.859 & 0.836 & 0.0439 & NS & NS & NS \\
\hline Initial body weight (kg) & 10.5 & 9.1 & 9.9 & 11.3 & 1.34 & NS & NS & NS \\
\hline Final body weight $(\mathrm{kg})$ & 26.8 & 22.2 & 23.8 & 24.1 & 2.36 & NS & NS & NS \\
\hline Average daily gain (g) & 88.6 & 72.1 & 77.7 & 70.4 & 2.76 & NS & $*$ & NS \\
\hline $\mathrm{DM} /$ gain $\left(\mathrm{kg} \mathrm{kg}^{-1}\right)$ & 6.9 & 7.3 & 7.7 & 8.4 & 0.34 & $* *$ & $*$ & NS \\
\hline $\mathrm{CP} /$ gain $\left(\mathrm{kg} \mathrm{kg}^{-1}\right)$ & 1.0 & 1.2 & 1.2 & 1.3 & 0.05 & $* *$ & $* *$ & NS \\
\hline DE/gain $\left(\mathrm{MJ} \mathrm{kg}^{-1}\right)$ & 85.58 & 97.72 & 90.79 & 99.05 & 5.067 & NS & $* *$ & NS \\
\hline \multicolumn{9}{|l|}{ Wool production } \\
\hline Growth $\left(\mathrm{mg} 100^{-1} \mathrm{~cm}^{2}\right)$ & 93.8 & 124.6 & 104.6 & 109.6 & 8.68 & NS & $* *$ & $*$ \\
\hline Staple length $(\mathrm{cm})$ & 5.8 & 6.2 & 5.4 & 6.7 & 0.53 & NS & $*$ & NS \\
\hline Fibre diameter $(\mu \mathrm{m})$ & 40.9 & 36.8 & 40.4 & 34.5 & 4.90 & NS & NS & NS \\
\hline
\end{tabular}

${ }^{\mathrm{a}}$ Number of observations per mean $=6$.

$*, * *, * * *, \mathrm{NS}=P<0.05, P<0.01, P<0.001, P>0.05$, respectively. 
Table 7

Blood biochemical constituents of growing lambs fed rations containing UTNSKC as a replacement of GNC

\begin{tabular}{|c|c|c|c|c|c|c|c|c|}
\hline & \multicolumn{2}{|l|}{ GNC } & \multicolumn{2}{|c|}{ UTNSKC } & \multirow[t]{2}{*}{$\mathrm{Sed}^{\mathrm{a}}$} & \multicolumn{3}{|c|}{ Significance of difference } \\
\hline & Male & Female & Male & Female & & $\begin{array}{l}\text { Protein } \\
\text { source }(\mathrm{P})\end{array}$ & $\begin{array}{l}\text { Sex } \\
(\mathrm{S})\end{array}$ & $\mathrm{P} \times \mathrm{S}$ \\
\hline Glucose $\left(\mathrm{mg} \mathrm{l}^{-1}\right)$ & 768 & 685 & 759 & 758 & 599.0 & NS & NS & NS \\
\hline Blood urea nitrogen $\left(\mathrm{mg} \mathrm{l}^{-1}\right)$ & 200 & 225 & 195 & 211 & 246.2 & NS & NS & NS \\
\hline SGOT $^{\text {b }}$ (i.u. $1^{-1}$ ) & 28.2 & 32.7 & 31.2 & 32.0 & 2.21 & NS & NS & NS \\
\hline SGPT $^{\text {c }}$ (i.u. $1^{-1}$ ) & 17.6 & 18.5 & 19.9 & 16.7 & 1.33 & NS & NS & NS \\
\hline Alkaline phosphatase (i.u. $1^{-1}$ ) & 151.8 & 126.2 & 109.7 & 109.3 & 21.32 & NS & NS & NS \\
\hline
\end{tabular}

${ }^{\mathrm{a}}$ Number of observations per mean $=6$.

${ }^{\mathrm{b}}$ Serum glutamate-oxaloacetate transaminase.

${ }^{\mathrm{c}}$ Serum glutamate-pyruvate transaminase.

*, **, ***, NS $=P<0.05, P<0.01, P<0.001, P>0.05$, respectively.

All visceral organs were normal on gross pathological examination except the kidneys which were enlarged in lambs fed UTNSKC $(P<0.05)$. Histopathological examination of kidneys from animals which were slaughtered showed the presence of microcalculi in collecting tubules of medulla region of all lambs fed UTNSKC, while none was present in those on control diet.

\section{Discussion}

\subsection{Digestibility study}

Replacement of GNC with UTNSKC had no effect on palatability as is evident from similar intakes of concentrate offered (Table 2). This observation is similar to earlier studies where NSKC (Rajagopal and Nath, 1981), water-washed neem seed kernel cake (WWNSKC) (Agrawal et al., 1987; Nath et al., 1989) and UTNSKC (Reddy, 1992) totally replaced GNC in concentrate mixtures. Lambs offered UTNSKC consumed more hay than those on GNC resulting in higher intake of DM. Gupta and Bhaid (1981) also reported higher intake of DM on diets containing neem seed cake (NSC).

The depression in digestibility of DM on the ration containing UTNSKC agrees with observations by Agrawal et al. (1987) in buffalo calves fed a concentrate mixture containing WWNSKC. However, in other studies, no such depression was observed on feeding a concentrate mixture containing $45 \%$ NSKC

Table 8

Carcass characteristics and size of visceral organs of male lambs fed UTNSKC as a replacement of GNC

\begin{tabular}{|c|c|c|c|c|}
\hline Attribute & GNC & UTNSKC & $\mathrm{Sed}^{\mathrm{a}}$ & Significance \\
\hline Carcass weight $(\mathrm{kg})$ & 12.2 & 10.5 & 1.75 & NS \\
\hline Killing-out yield (\%) & 48.1 & 46.8 & 1.45 & NS \\
\hline Rib eye area $\left(\mathrm{cm}^{2}\right)$ & 8.4 & 8.1 & 1.44 & NS \\
\hline \multicolumn{5}{|c|}{ Size of visceral organs $\left(\mathrm{g} \mathrm{kg}^{-1}\right.$ pre-slaughter weight) } \\
\hline Liver & 14 & 17 & 1.6 & NS \\
\hline Kidney & 2 & 3 & 0.2 & $*$ \\
\hline Heart & 4 & 4 & 0.6 & NS \\
\hline \multicolumn{5}{|l|}{ Gastrointestinal tract } \\
\hline Full & 209 & 254 & 27.7 & NS \\
\hline Empty & 75 & 82 & 6.4 & NS \\
\hline
\end{tabular}

${ }^{\text {a }}$ Number of observations per mean $=4$.

$*, * *, * * *, \mathrm{NS}=P<0.05, P<0.01, P<0.001, P>0.05$, respectively. 
(Rajagopal and Nath, 1981), 45\% WWNSKC (Nath et al., 1983) or 30\% UTNSKC (Reddy, 1992). The results in this study are similar to those of Reddy (1992) who reported a depression of $6.8 \%$ in the digestibility of CP in buffalo calves fed UTNSKC. However, in other studies, comparable values were reported on rations containing untreated NSKC (Rajagopal and Nath, 1981) or after water washing (Nath et al., 1983, 1989; Agrawal et al., 1987; Sastry and Agrawal, 1992).

Lambs on both rations were in positive $\mathrm{N}$ balance. Rajagopal and Nath (1981) observed similar N retention on feeding rations containing NSKC and GNC. Nath et al. (1983), on the other hand reported lower $\mathrm{N}$ retention when rations containing WWNSKC were fed. However, utilisation of $\mathrm{N}$ after absorption was not affected by diet differences. In other studies, improved utilisation of $\mathrm{N}$ was reported on rations containing WWNSKC because of reduced loss of $\mathrm{N}$ in urine (Agrawal et al., 1987; Sastry and Agrawal, 1992).

Though the animals were offered the same amount of concentrates, the higher intake of hay by the lambs given concentrate mixture containing UTNSKC was attributed to the supply of less DE from the concentrate offered. Rajagopal and Nath (1981) also reported similar intakes of DE and ME by calves fed concentrate mixtures containing either NSKC (45\%) or GNC $(30 \%)$.

\subsection{Rumen fermentation study}

In this study, changes in $\mathrm{pH}$ varied with the TVFA concentration in the rumen. Garg (1989) reported similar observations on feeding NSC. However, Reddy (1992) did not observe any difference in the rumen $\mathrm{pH}$ from feeding UTNSKC but reported higher TVFA production. The lower total and ammonia $\mathrm{N}$ in the rumen liquor from lambs fed UTNSKC is in agreement with earlier studies on rations containing water-washed neem seed cake (Garg, 1989) and alkali-treated neem seed kernel cake (Reddy, 1992). Similarly, in this study the low activities of protease and urease in the rumen may explain the lower concentration of total and ammonia $\mathrm{N}$ in the rumen liquor. The depressed activity of cellulase in the present study is in agreement with the observation of Garg (1989). On the other hand, Agarwal et al. (1991) reported that water extract of NSKC stimulated cellulase activity in vitro. Similarly, the depressed digestibility of nutrients on the ration containing UTNSKC may be attributed to the lower activities of the rumen enzymes.

\subsection{Performance of lambs}

There was no difference in the growth of wool and the daily live weight gain of lambs on the two rations. This was attributed to the similar intake of DE by animals on the two diets. Reddy (1992) and Anandan et al. (1996) also reported comparable growth rate in buffalo calves and growing goats, respectively, fed rations containing either GNC or UTNSKC. On the other hand, wool growth was higher in female lambs, which had lower average daily gains as compared to male lambs. Such negative correlation between growth rate and wool growth was postulated to be due to diversion of partitioned nutrients in the body towards growth of various organs (Oddy and Annison, 1979).

The mean carcass weight and killing out percentage of lambs did not differ between diets. In line with the study of Reddy (1992), feeding UTNSKC did not affect the dressing percentage and rib eye area as compared to animals on control ration. Though the yield of liver and gastrointestinal tract in the present study was not significantly different, it was higher in lambs fed UTNSKC. However, the yield of kidney was higher in lambs fed UTNSKC. Similar results were reported by Reddy (1992) on feeding UTNSKC. In agreement with the present study, Burrin et al. (1990) attributed the high proportion of visceral organs to body mass to increased DM intake.

\subsection{Toxicity}

The bitter compounds in neem are known to have an antihyperglycaemic effect (Bhargava et al., 1985). Garg (1989) found that feeding NSC after waterwashing to cattle calves still lowered significantly the blood glucose levels as compared to those on control ration. However, in the present study UTNSKC did not show any antihyperglycaemic effect in agreement with the study of Reddy (1992). In the present study, there was no difference in the serum activities of alkaline phosphatase, SGOT and SGPT due to ration. Similar results were also reported on rations containing WWNSKC (Nath et al., 1983, 
1989) and UTNSKC (Reddy, 1992). Blood urea N concentration was not affected by ration, in agreement with the study of Reddy (1992) with buffalo calves fed UTNSKC.

There were no pathological changes associated with feeding UTNSKC except for the presence of microcalculi in the kidney. Urinary calculi has been associated with low pH of urine (Bushman et al., 1967) and elevated level of phosphorus in urine (Bushman et al., 1965). However, these were not monitored in the present study and this aspect requires further investigation.

\section{Conclusion}

Results in this study indicated that UTNSKC was a satisfactory replacement of GNC in the concentrate mixture for growing lambs. However, the presence of microcalculi in the kidney needs further investigation especially under cases of long term feeding.

\section{Acknowledgements}

The first author was a recipient of the commonwealth fellowship by the Indian Council for Cultural Relations. This work was part of Ph.D. dissertation supported by grants from Indian Council for Agricultural Research. The authors are grateful to Mr. G.S. Bisht for his assistance in statistical analysis of the data.

\section{References}

Agrawal, D.K., Garg, A.K., Nath, K., 1987. The use of water washed neem (Azadirachta indica) seed kernel cake in feeding of buffalo calves, short note. J. Agric. Sci. (Camb.) 108, 497-499.

Agarwal, N., Kewalramani, N., Kamra, D.N., Agrawal, D.K., Nath, K., 1991. Effect of water extracts of neem (Azadirachta indica) on the activity of hydrolytic enzymes of mixed rumen bacteria from buffalo. J. Sci. Food Agric. 57, 147-150.

Anandan, S., Sastry, V.R.B., Musalia, L.M., Agrawal, D.K., 1996. Growth rate and nutrient efficiency of growing goats fed urea ammoniated neem (Azadirachta indica) seed kernel meal as protein supplement. Small Rumin. Res. 22, 205-212.

AOAC, 1984. Official Methods of Analysis of the Association of Official Analytical Chemists, 13th ed., Washington, DC, pp. 125-131.
Bergmeyer, H.U., 1974. Methods of Enzymatic Analysis, vol. 2. Academic press, New York, pp. 856-860.

Bhargava, A.K., Dwivedi, S.K., Singh, G.R., 1985. A note on the use of neem oil (Azadirachta indica) as antihyperglycaemic agent in dogs. Indian J. Vet. Surg. 6, 66-67.

Burrin, D.G., Ferrell, C.L., Britton, R.A., Baner, M., 1990. Level of nutrition and visceral organ size and metabolic activity in sheep. Brit. J. Nutr. 64, 439-448.

Bushman, B.H., Emerick, R.J., Embry, L.B., 1965. Incidence of urinary calculi in sheep as affected by various dietary phosphates. J. Anim. Sci. 24, 671-675.

Bushman, D.H., Embry, L.B., Emerick, R.J., 1967. Efficiency of various chlorides and calcium carbonate in the prevention of urinary calculi. J. Anim. Sci. 26, 1199-1204.

Cooper, G.R., McDaniel, 1970. Standard Methods of Clinical Chemistry. Academic press, New York, 159 pp.

Deriaz, R.E., 1964. Routine analysis of carbohydrates and lignin in herbage. J. Sci. Food Agric. 12, 152-160.

Garg, A.K., 1989. Studies on deoiled neem (Azadirachta indica) seed cake as cattle feed, Ph.D. Thesis, Indian Veterinary Research Institute, Izatnagar, India.

Gupta, R.S., Bhaid, M.V., 1981. Studies on agro-industrial byproducts: Deoiled neem fruit cake in sheep feed composition. Indian Vet. J. 58, 311-315.

Hogg, M.L., 1967. Methods for the estimation of urea in foods. In: Briggs, M.H. (Ed.), Urea as a Protein Supplement. Pergamon press, London, pp. 455-461.

Katiyar, R.C., Sastry, V.R.B., Agrawal, D.K., 1991. Urea and Alkali Treated Neem Seed Kernel Cake as Livestock Feed. Annual report. Animal Nutrition Division. Indian Veterinary Research Institute. Izatnagar, India.

Lowry, O.H., Rosebrough, N.J., Farr, A.L., Randall, R.C., 1951. Protein measurement with Folin-phenol reagent. J. Biol. Chem. 193, 265-275.

Miller, G.L., 1959. Modified DNS methods for reducing sugars. Anal. Chem. 31, 426-428.

Nagalakshmi, D.N., 1993. Performance of broiler chicks fed processed neem (Azadirachta indica) as a protein supplement. M.V.Sc. Thesis. Indian Veterinary Research Institute. Izatnagar, India, pp. 126-130.

Nath, K., Rajagopal, S., Garg, A.K., 1983. Water washed neem (Azadirachta indica) seed kernel cake as a cattle feed. J. Agric. Sci. (Camb.) 101, 323-326.

Nath, K., Agrawal, D.K., Hassan, Q.Z., Daniel, S.J., 1989. Water washed neem (Azadirachta indica A. juss) seed kernel cake in the feeding of milch cows. Anim. Prod. 48, 497-502.

NRC, 1985. Nutrient Requirements of Sheep. National Academy press, Washington, DC.

Oddy, V.H., Annison, E.F., 1979. Possible mechanisms by which physiological state influences the rate of wool growth. In: Black, J.L., Reis, P.J. (Eds.), Physiological and Environmental Limitation to Wool Growth. University of New England Publishing Unit, Armidale, pp. 295-310.

Rahmatulla, M., Boyde, T.R.C., 1980. Improvement in the determination of urea using diacetylmonoxide method with or without deproteinization. Clin. Chim. Acta. 107, 3-9. 
Rajagopal, S., Nath, K., 1981. Note on the nutritive value of cake of neem seed kernel. Indian J. Anim. Sci. 51, 661-663.

Reddy, K.V.C., 1992. Performance of buffalo (Bubalus bubalis) calves fed alkali treated and urea-ammoniated neem (Azadirachta indica. A. juss) seed kernel cake incorporated rations. M.V.Sc Thesis, Indian Veterinary Research Institute, Izatnagar, India.

Reitman, S., Frankel, S., 1957. A calorimetric method for determination of serum glutamic oxaloacetic transaminase and serum glutamic pyruvic transaminase. Am. J. Clin. Path. $28,56-63$

Sastry, V.R.B., Agrawal, D.K., 1992. Utilization of water washed neem (Azadirachta indica) seed kernel cake as a protein source for pigs. J. App. Anim. Res. 1, 103-107.

Snedecor, G.W., Cochran, W.G., 1980. Statistical Methods, 6th ed. Oxford and IBH Publishing company, New Delhi, pp. 258-298.

Weatherburn, M.W., 1967. Phenol hypochlorite reaction for determination of ammonia. Anal. Chem. 39, 971-974. 